\title{
ZJAZD RODZINNY JAKO PRZYKŁAD WYNALEZIONEJ TRADYCJI
}

DOROTA FERET

\begin{abstract}
Wydział Nauk Humanistycznych Uniwersytetu Kardynała Stefana Wyszyńskiego; Faculty of Humanities Cardinal Stefan Wyszyński University in Warsaw (Poland) dorotaferet@onet.pl
\end{abstract}

Celem niniejszego artykułu jest ukazanie, że współcześnie dyskutowane problemy dotyczące wynalezionych tradycji oraz pamięci zbiorowej zachodzą również na mikropoziomie. Eric Hobsbawm i Terence Ranger w Tradycji wynalezionej opisywali mechanizmy tworzenia tradycji większych wspólnot, zajmując się państwami czy narodami ${ }^{1}$. Podobnie jest z badaniem pamięci zbiorowej, gdyż głównie analizuje się pamiętanie w wymiarze globalnym, narodowym oraz lokalnym. Natomiast przedmiotem badań w tym artykule jest I Zjazd Rodu Feretów, który został potraktowany jako tradycja wynaleziona skonstruowana w odpowiedzi na kryzys ponowoczesnego społeczeństwa. $\mathrm{Z}$ pomocą teorii naukowych z zakresu szeroko pojętych badań nad przeszłością postaram się przedstawić mechanizmy oraz intencje budowania tradycji oraz pamięci podstawowej komórki społecznej, jaką jest rodzina.

Analiza zjawisk i procesów zachodzących na zjeździe była możliwa dzięki obserwacji uczestniczącej. W trakcie zjazdu badałam reakcje uczestników, wysłuchiwałam komentarzy oraz przyglądałam się relacjom rodzącym się między członkami rodziny. Zebrane materiały, takie jak prezentacja historii, kronika oraz hymn rodzinny, pozwoliły mi na analizę mechanizmów wytwarzania tradycji i pamięci.

${ }^{1}$ E. Hobsbawm, T. Ranger, Tradycja wynaleziona, tłum. M. Godyń, F. Godyń, Wydawnictwo Uniwersytetu Jagiellońskiego, Kraków 2008. 
W analizie I Zjazdu Rodu Feretów będę posługiwać się teoriami badaczy zajmującymi się pamięcią zbiorową i tradycją. Koncepcja tradycji wynalezionych Hobsbawma i Rangera pozwoli na zdefiniowanie zjazdu oraz przedstawienie jego konstrukcji i celów. Pojęcie pamięci zbiorowej wprowadzone przez Maurice’a Halbwachsa pozwoli zrozumieć, jak wynaleziona tradycja organizuje kolektywną pamięć rodziny oraz tworzy jej tożsamość. Odnosząc się do pamięci kulturowej w rozumieniu Jana Assmanna, należy mieć na uwadze, jak pamięć o przeszłości przejawia się w rzeczach materialnych oraz to, jak te ,pamiątki z przeszłości” wpływają na kształt wynalezionej tradycji rodziny. Dzięki rozważaniom Waldemara Kuligowskiego na temat zetknięcia się tradycji z globalizacją możliwe będą refleksje na temat zagrożeń dla rodziny i tradycji ze strony współczesnego świata.

Analizując sytuacje, w jakich dochodzi do potrzeby tworzenia nowych tradycji, Hobsbawm zauważa, że proces ten najczęściej zachodzi tam, gdzie następują gwałtowne zmiany społeczne, oraz tam, gdzie osłabiają się systemy wartości i wzory postępowania². Wynaleziona tradycja jest dla badacza świadectwem przemian oraz symptomem problemów, a jej konstruowanie służy wyjaśnianiu skomplikowanej teraźniejszości ${ }^{3}$. W. Kuligowski w Antropologii współczesności $i^{4}$ przedstawia epizody, w których spotykają się lokalne tradycje z globalną nowoczesnością i innowacjami. Stwierdza, że tradycja jest wartością, którą należy chronić, ale jednocześnie widzi potrzebę jej adaptacji do współczesnego świata. Jeżeli globalizacja jest zmianą społeczną przyczyniającą się do osłabienia systemów wartości, to trzeba ją potraktować jako zagrożenie dla rodziny. Ponadto w socjologii pojawiła się teza o kryzysie rodziny, który wynika ze stopniowego przejmowania funkcji rodziny przez

${ }^{2}$ Ibidem, s. 13.

${ }^{3}$ Ibidem, s. 20.

${ }^{4}$ W. Kuligowski, Prefabrykacja tradycji, promocja dziedzictwa, [w:] tegoż, Antropologia wspótczesności. Wiele światów, jedno miejsce, Kraków 2007. 
inne instytucje 5 . W książce Przemiany więzi społecznych Mirosława Marody i Anna Giza-Poleszczuk wyróżniają dwa stanowiska wyjaśniające wymiar owego kryzysu rodziny. Pierwsze z nich mówi nie tyle o zaniku rodziny, ile o zmianie jej formy ${ }^{6}$. Drugie stanowisko dotyczy kryzysu zagrażającego „podstawom istnienia społeczeństwa”, gdyż dezintegracja rodziny wynika z indywidualistycznego ustroju, w którym „szczęście osobiste przekłada się nad poczucie lojalności i obowiązku"». Zatem kryzys rodziny, liczne migracje, odległości dzielące krewnych, brak wiedzy na temat przeszłości własnej rodziny, brak kontaktu między jej członkami sprawiają, że rodzina traci poczucie jedności.

\section{Zjazd Rodu Feretów, czyli wynaleziona tradycja}

Hobsbawm twierdzi, że błędnie rozumie się tradycję, ponieważ „uważane za prastare lub jako takie przekazywane, mają rodowód całkiem niedawny, a czasem wręcz zmyślony”. Tradycję wynalezioną definiuje jako „zespół działań o charakterze rytualnym lub symbolicznym [...], działania te mają wpajać ludziom pewne wartości i normy zachowania przez ciągłe repetycje - co siłą rzeczy sugeruje kontynuowanie przeszłości”" ${ }^{10}$. Związek między przeszłością a teraźniejszością wytwarzany jest sztucznie, jednak przeszłość ingerująca w teraźniejszość jest poddawana interpretacjom w odniesieniu do aktualnych wydarzeń. W wynalezionych tradycjach najważniejszą cechą jest powtarzalność pewnych praktyk.

Konstrukcja I Zjazdu Rodu Feretów opierała się na wytworzeniu relacji między przeszłością a teraźniejszością. Żeby zbudować wewnętrzną jedność

${ }^{5}$ M. Marody, A. Giza-Poleszczuk, Przemiany więzi społecznych, Warszawa 2004, s. $185-191$.

${ }^{6}$ Ibidem, s. 215.

${ }^{7}$ Ibidem.

${ }^{8}$ Ibidem.

${ }^{9}$ E. Hobsbawm, T. Ranger, Tradycja wynaleziona, op. cit., s. 9.

${ }^{10}$ Ibidem, s. 10. 
grupy, organizatorzy musieli zapoznać uczestników zjazdu z historią rodziny, przodkami oraz miejscem ich pochodzenia. Wiele czasu poświęcono na przekazywanie wartości, dzięki którym sama idea zjazdu jako praktyka kulturowa oraz zbudowana podczas niego tożsamość grupy mogły przetrwać.

I Zjazd Rodu Feretów odbył się 31 marca 2013 roku w Gościnie (woj. zachodniopomorskie). Pomysłodawczynią wydarzenia była Krystyna Zielińska, która zgromadziła przy wielkanocnym stole 67 członków rodziny. W oczekiwaniu na rozpoczęcie spotkania uczestnicy podziwiali drzewo genealogiczne. Każdy został serdecznie powitany przez gospodynię zjazdu i otrzymał przypinkę z wizerunkiem założycieli rodu oraz broszurę informacyjną zawierającą historię rodziny, genealogię, hymn rodzinny oraz teksty piosenek.

\section{Budowanie tożsamości}

Hobsbawm wyróżnia trzy typy wynalezionych tradycji, które służą budowaniu tożsamości grupowej, wpajaniu pewnych wartości i konwencjonalnych sposobów zachowania oraz legitymizacji i umocnieniu instytucji ${ }^{11}$. Wojciech Burszta zwraca uwagę na to, że kształtowanie tożsamości przez grupę za pomocą wymyślania tradycji odbywa się w świadomy i dobrowolny sposób ${ }^{12}$. Dla organizatorów zjazdu niewątpliwie jednym z priorytetów było więc intencjonalne wykreowanie symbolicznej jedności rodziny. Pierwszym punktem programu była uporządkowana i spójna narracja o rodzinie, czyli prezentacja wszystkich członków oraz przedstawienie historii całego rodu za pomocą wyświetlanych zdjęć. Na początku ukazało się zdjęcie Marii i Władysława - założycieli rodu, którzy mieszkali w Tuszkowie ${ }^{13}$.

${ }^{11}$ Ibidem, s. 17 .

${ }^{12} \mathrm{~W}$. Burszta, Różnorodność i tożsamość. Antropologia jako kulturowa refleksyjność, Poznań 2004, s. 109-113.

${ }^{13}$ Do 1951 roku Tuszków mieścił się w granicach Polski, leżał między Worochtą a Bełzem nad Rzeczycą. Obecnie znajduje się na terenie Ukrainy i nosi nazwę Zabłocie (ang. Zabolottya). 
Następnie przedstawiono ich dzieci, czyli pięciu braci. Zaprezentowano też historię oraz rodzinę każdego z nich. W ten sposób ukazano mit założycielski, przeszłość rodu oraz wszystkich 118 członków rodziny.
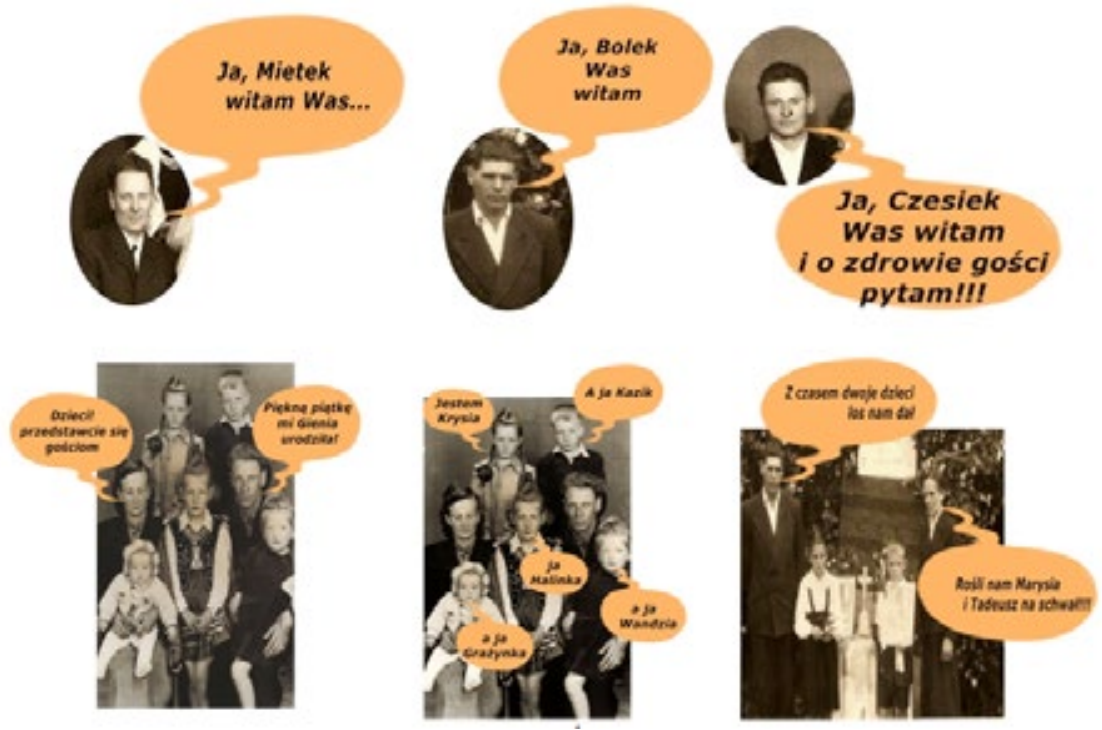

Ilustracja nr 1. Slajd z prezentacji. Źródło - archiwum prywatne

Według Halbwachsa wiedza o przeszłości jest niezbędna do podtrzymywania tożsamości. Najważniejsze w kształtowaniu tej wiedzy są subiektywne wspomnienia oraz relacje jednostek ${ }^{14}$, które w przypadku zjazdu stały się podstawą do rekonstrukcji przeszłości rodziny. Pomysłodawczyni, tworząc program imprezy, musiała dobrze poznać historię rodu, opierając się na wspomnieniach i rozmowach z Czesławem Feretem. Opowieści zostały zapisane w założonej wtedy kronice, a chwilę spisywania historii rodziny uwieczniono na zdjęciu, które pokazano na zjeździe. Rozmowy odbyte

${ }^{14}$ M. Saryusz-Wolska, Wprowadzenie, [w:] Pamięć zbiorowa i kulturowa. Współczesna perspektywa niemiecka, red. M. Saryusz-Wolska, Kraków 2009, s. 22. 
podczas spotkania ujawniły, jak bardzo uczestnikom zależy na wiedzy dotyczącej rodzinnej przeszłości.

Istotnym zabiegiem $\mathrm{w}$ procesie identyfikacji jednostek $\mathrm{z}$ grupą było analizowanie drzewa genealogicznego. Każdy uczestnik zobligowany był do uzupełnienia na tablicy informacji o potomkach Władysława Fereta. Dzięki uświadomieniu sobie wspólnego pochodzenia członkowie rodziny znaleźli podstawę do identyfikacji z grupą. Taką funkcję pełniły też przypinki z logo zjazdu. Wizerunek założycieli rodu stał się symbolem zjazdu oraz rodziny. Wyrażał wewnętrzną jedność grupy, budował jej tożsamość oraz poczucie przynależności do grupy. Widząc przypinki na ubraniach nieznajomych do tej pory osób, uczestnicy mogli dostrzec wizerunek wspólnych przodków. Portret Władysława i Marii Feretów stał się również symbolem mitu założycielskiego. Założenie rodziny - tak powszechne i zwyczajne zjawisko - zostało potraktowane jako pewien historyczny moment godny utrwalenia. Przedstawiona historia wykreowała wyidealizowany obraz rodziny. Traumatyczne wydarzenia związane z wojną, przesiedleniami czy tragiczną śmiercią Władysława ${ }^{15}$ były niejako ukryte pod szyldem praktyk pamiętania.

Mit założycielski obecny był także w ułożonym na tę okazję hymnie, śpiewanym na melodię piosenki Ach mazurskie, jakie cudne. Hobsbawm, opisując tworzenie tożsamości, wskazuje na to, że hymny państwowe to właśnie wynalezione tradycje ${ }^{16}$. Hymn Feretów nie przestrzega ściśle wymogów formalnych gatunku i nie spełnia kryteriów literackich. Pomimo tego nadanie mu przez rodzinę funkcji pieśni pozwala odróżnić ich wspólnotę od innych grup społecznych i kształtować jej tożsamość. Odwołując się do typu wynalezionej tradycji,

${ }^{15}$ K. Bulzacki, H. Komański, S. Siekierka, Ludobójstwo dokonane przez nacjonalistów ukraińskich na Polakach w województwie lwowskim 1939-1947, Wrocław 2006, s.998.

${ }^{16}$ E. Hobsbawm, T. Ranger, Tradycja wynaleziona, op. cit., s. 15. 


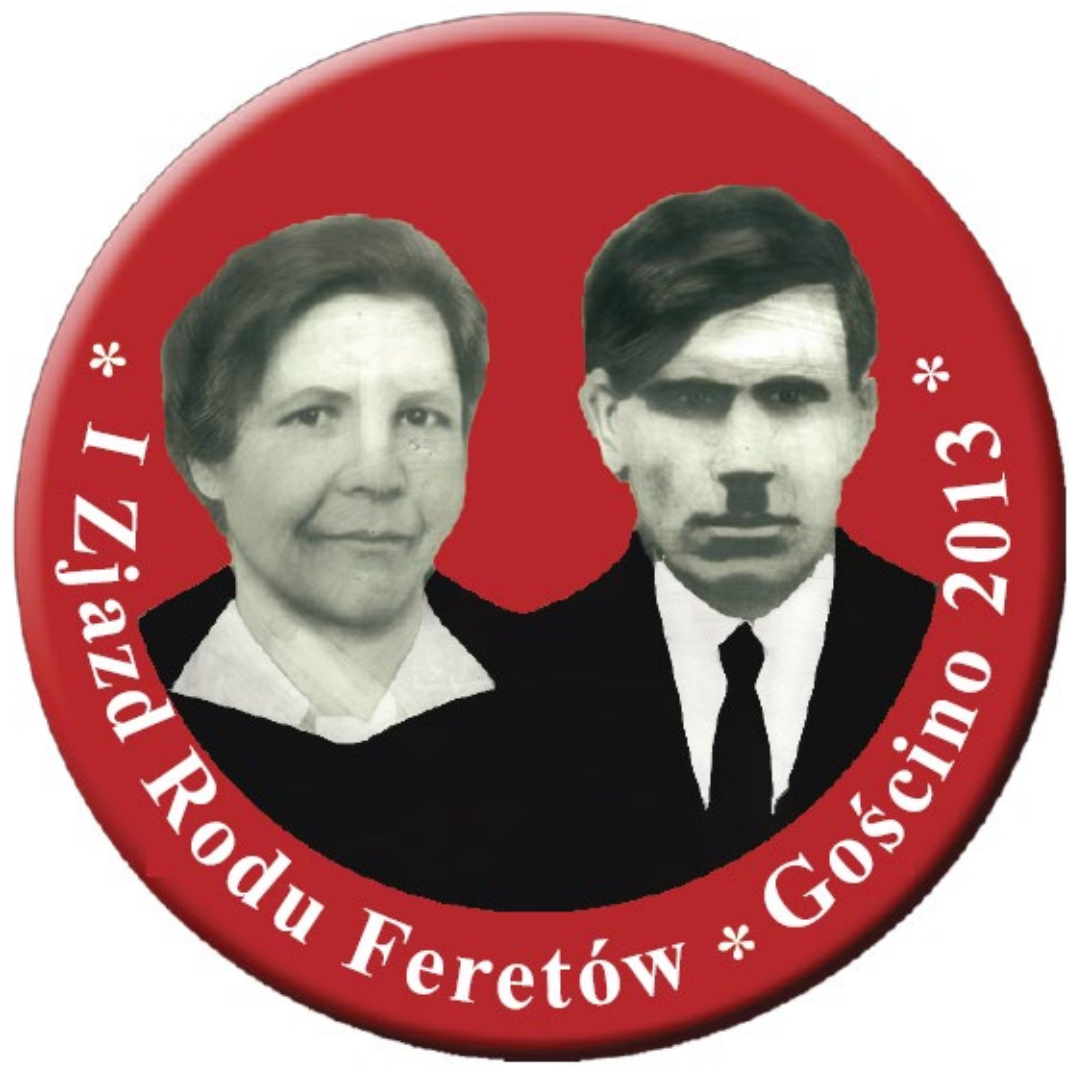

Ilustracja nr 2. Logo Zjazdu. Źródło - archiwum prywatne

który wyróżnił Hobsbawm, można stwierdzić, że powstanie hymnu Feretów jest również przejawem umacniania oraz legitymizacji instytucji rodziny ${ }^{17}$.

Pierwsze słowa hymnu wyjaśniają, skąd pochodzi rodzina. Następnie przedstawiona zostaje krótka historia przodków oraz opis charakterystycznych, często żartobliwych cech każdej z rodzin.

\footnotetext{
${ }^{17}$ Ibidem, s. 17.
} 
Hej, ten Tuszków ukochany, gdzie Feretów powstał ród. Skąd w świat poszło pięciu braci uszczęśliwić żony swe [...] Tu w Gościnie Zjazd nasz pierwszy w głowie Krychy zrodził się. Bierzcie przykład, powielajcie, zapraszajcie w strony swe.

Apel zawarty w przywołanej pierwszej zwrotce hymnu zakłada, że zjazd jest przejawem zacieśniania więzi rodzinnych - działania godnego naśladowania. Edward Shils, wskazując na ,intencjonalne traktowanie pewnych przekazów kulturowych jako godnych miana tradycji" ${ }^{18}$, zauważa, że jest ona procesem dynamicznym, gdyż stale odtwarza treści i formy kulturowe, przy czym powoduje zmiany społeczne i kulturowe w życiu obywateli ${ }^{19}$. O tym, że pewne wytwory uznawane są za godne utrwalania i powtarzania z racji mniemania o ich dawności, pisał nie tylko Shils, lecz także Hobsbawm i Kuligowski. Jednak nowo powstała koncepcja zjazdu nie odwołuje się do dawnych czasów, wzorów czy tradycji, lecz tworzy własne reguły, co jest charakterystyczne dla pojęcia tradycji wynalezionej. To właśnie hymn konstytuuje tę tradycję, mówiąc o niej jako o przykładzie wartym powielania. O realnym oddziaływaniu słów hymnu świadczą liczne wpisy w kronice, w których pojawiają się zaproszenia i wyrażone nadzieje na kolejne zjazdy. „Często nas odwiedzajcie!”; „Dla wszystkich drzwi naszego domu otwarte”; „Jadąc na wschód do Rzeplina, Lubyczy Królewskiej, Tuszkowa, Bełza i Lwowa, nie omijajcie Okszowa" - takie słowa umieszczały rodziny wpisujące się do kroniki. Potwierdzeniem tych zaproszeń było podawanie dokładnych adresów, numerów telefonów oraz adresów e-mailowych. Przywołane przykłady doskonale obrazują pogląd Shilsa mówiący o tym, że tradycja powoduje zmiany społeczne i kulturowe w życiu społecznym.

${ }^{18}$ Ibidem, s. 10.

19 E. Shils, Tradycja, tłum. J. Szacki, [w:] Tradycja $i$ nowoczesność, red. J. Kurczewska, J. Szacki, Warszawa 1984. 


\section{Wpajanie wartości i norm}

Według Hobsbawma tradycje wynalezione tworzy się również po to, by rozpowszechniać i wpajać pewne wartości i normy oraz konwencjonalne sposoby zachowania ${ }^{20}$. Podczas I Zjazdu Rodu Feretów przekonywano członków rodziny do postępowania w określony sposób poprzez apel do rodziny oraz ceremonię wręczenia nagród Feret 2013.

Prezentację historii pięciu braci i ich rodzin zakończono apelem do rodziny, który brzmiał następująco:

Więc Ferety pamiętajcie, wszyscy jak tutaj siedzicie:

Dzieciom zapomnieć nie dawajcie.

Życzenia składajcie.

Na wesela zapraszajcie.

Wzajemnie się odwiedzajcie.

Więzi, która nas łączy, zaginąć się pozwalajcie!!!

Rodzina jako grupa początkowa jest odpowiedzialna za socjalizację pierwotną u najmłodszych jej członków, zatem na zjeździe wiele uwagi poświęcono przekonywaniu starszych o konieczności przekazywania wiedzy o przeszłości oraz podtrzymywania więzi rodzinnych. Pamięć o minionych wydarzeniach, którą daje się młodszym pokoleniom, jest jedyną szansą na podtrzymanie tożsamości grupowej. Dlatego apel „dzieciom zapomnieć nie dawajcie” znalazł się na pierwszym miejscu normatywnych zachowań.

Rolę starszego pokolenia w kształtowaniu świadomości historycznej u dzieci podkreślał Halbwachs, wskazując na to, że rodzina jest odpowiedzialna za pierwszy etap formowania się pamięci społecznej. Badacz zwrócił uwagę na istotną w tym procesie rolę dziadków, gdyż ,przekażą oni wnukom fragmenty własnych wspomnień w przerwach aktualnego życia rodzinnego"21. Dzięki temu poznaje się przeszłość rodziny oraz historię powszechną.

${ }^{20}$ E. Hobsbawm, T. Ranger, Tradycja wynaleziona, op. cit., s. 17.

${ }^{21}$ M. Halbwachs, Społeczne ramy pamięci, tłum. M. Król, Warszawa 1969, s. 252. 
Proces ten zaszedł również podczas prezentacji przeszłości rodziny Feretów. Podane na zjeździe informacje na temat śmierci Władysława Fereta pozwoliły nakreślić szerszy kontekst na temat działalności oraz ataków UPA na polską ludność cywilną. Emigracja przodków, która była konsekwencją przesiedleń związanych z przesunięciem granicy na podstawie porozumień w Jałcie i Poczdamie w 1945 roku oraz umowy o zmianie granic z 1951 roku² ${ }^{22}$ umożliwiła zrozumienie tego, jak kształtowała się Europa po II wojnie światowej. Uświadomienie sobie tego, że pewne fakty historyczne miały realny wpływ na losy rodziny, wzbogaciło wiedzę rodziny o historii powszechnej.

Z kolei apel „Wzajemnie się odwiedzajcie” jest postulatem utrzymywania więzi rodzinnych, który zawiera również przyjęty wizerunek rodziny. Powstaje ona w momencie zawarcia związku małżeńskiego, powiększa się i umiera ${ }^{23}$. Teorię tę odzwierciedla sposób przedstawienia poszczególnych rodzin, gdzie kluczową rolę odegrały fotografie ślubne. Wizerunek dominujący w przedstawianiu poszczególnych rodzin świadczy o normatywnym postulacie, jak powinien przebiegać proces jej rozwoju. Analogicznie, po fotografiach ślubnych ukazywały się zdjęcia uwieczniające przyjęcie sakramentów, takich jak chrzest czy pierwsza komunia święta, które przedstawiały uczestnikom „owoce” związku małżeńskiego.

Ciekawym punktem programu była ceremonia wręczania nagród Feret 2013, zawierająca wyraźny katalog wzorcowych zachowań. Statuetki wręczano m.in. w kategoriach: rozsławiania nazwiska, pamięci o życzeniach, honorowej reprezentacji na zjeździe. Przy dźwięku fanfar po czerwonym dywanie dumnie przechodzili członkowie rodziny, by otrzymać statuetki, na których widniał wizerunek założycieli rodu. Najważniejszą nagrodą była statuetka za czuwanie nad podtrzymywaniem więzi rodzinnych, wręczona

${ }^{22}$ Dz. U. z 1952 r. Nr 11, poz. 63, art.4.

${ }^{23}$ M. Marody, A. Giza-Poleszczuk, Przemiany więzi społecznych, op. cit., s. $186-187$. 

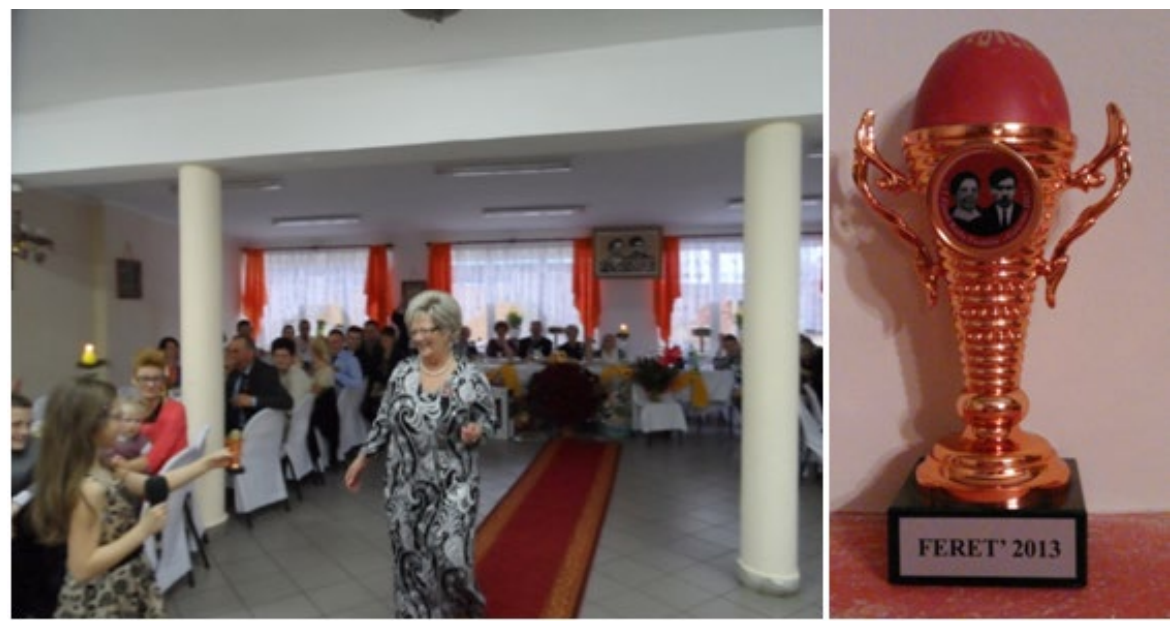

Ilustracja nr 3. Wręczenie nagrody. Źródło - archiwum prywatne

pomysłodawczyni i głównej organizatorce zjazdu - Krystynie Zielińskiej. Dzięki jej staraniom wszelkie zastosowane zabiegi stworzyły więź rodzinną między uczestnikami zjazdu, stanowiącą fundament, na którym została zbudowana tożsamość całego rodu. Nagroda w takiej kategorii sugeruje, jak ważna jest chęć utrzymywania kontaktów z rodziną, oraz nakłada na uczestników zjazdu nieformalny obowiązek podtrzymywania więzi i wynalezionej tradycji. Najskuteczniejszym do tego narzędziem jest pamięć.

\section{Pamięć zbiorowa i kulturowa}

Pojęcie ,pamięci zbiorowej”, wprowadzone przez Halbwachsa, wywołało największe zainteresowanie w latach 70. XX wieku. Jak twierdzą niektórzy badacze, Halbwachs nigdy precyzyjnie nie zdefiniował teoretycznych podstaw tej koncepcji i nigdy też nie zajmował się ich wyjaśnieniem²4. Można zatem spekulować, że problemy komunikacji w jej badaniach mają początek w nieostrości kategorii, którą wprowadza prekursor. Współcześnie metodologiczna i terminologiczna różnorodność w badaniu pamięci jest wynikiem

${ }^{24}$ N. Gedi, Y. Elam, Collective memory - What is it?, Paryż 1950. 
interdyscyplinarnego charakteru owej problematyki oraz podejścia uwarunkowanego przez pojedyncze dyscypliny. Naprzeciw problemom współczesnej refleksji nad pamięcią wychodzą autorzy książki Modi memorandi. Leksykon kultury pamięci, w której definiują pamięć zbiorową jako „podzielane przez członków grupy społecznej wyobrażenia dotyczące jej przeszłości; wytwory kulturowe powstałe w ramach grupy służącej pamiętaniu"25.

Relacja między wynalezioną tradycją a pamięcią zbiorową w kontekście I Zjazdu Rodu Feretów jest dwustronna, gdyż wynaleziona tradycja kształtuje pamięć grupy, a pamięć jest fundamentem, na którym została zbudowana wynaleziona tradycja. Przywołanie historii pięciu braci zdeterminowało wiedzę oraz pamięć o przodkach i przeszłości rodziny. Wiedza ta została uwarunkowana przez samą grupę społeczną, która wykreowała obraz przeszłości. Poszczególni uczestnicy nie mogli posiadać pamięci indywidualnej o przeszłości rodziny, gdyż po prostu nie byli jej świadkami. Jednak zabiegi zastosowane na zjeździe wytworzyły pamięć o przeszłości w wymiarze kolektywnym. Według Halbwachsa najskuteczniejszym narzędziem do podtrzymywania własnej tożsamości jest właśnie pamięćc ${ }^{26}$. Natomiast owa tożsamość i chęć zacieśniania więzi rodzinnych wytworzonych na zjeździe są główną przyczyną podtrzymywania wynalezionej tradycji.

Koncepcja pamięci zbiorowej zainspirowała Jana Assmanna, który przedstawił pojęcie „pamięci kulturowej”, definiując ją jako tę, która przybiera charakter zewnętrzny ${ }^{27}$. Grupa społeczna, chcąc zachować pamięć o przeszłości, wytwarza materialne i rytualne nośniki, które współcześnie określa się jako „nośniki pamięci” lub „media pamięci”. Assmann wyróżnia także pamięć

${ }^{25}$ Modi memorandi. Leksykon kultury pamięci, red. M. Saryusz-Wolska, R. Traba, Warszawa 2014, s. 346.

${ }^{26} \mathrm{~F}$. Pazderski, Czemu przeszłość się pamięta - wokót dyskusji na temat kształtowania się pamięci zbiorowej, $\mathrm{nr} 2$, s. 5.

${ }^{27}$ J. Assmann, Pamięć kulturowa. Pismo, zapamiętywanie i polityczna tożsamość w cywilizacjach starożytnych, thum. A. Kryczyńska-Pham, Warszawa 2008. 
komunikacyjną, która oznacza wyobrażenia o przeszłości w obrębie rodziny, przekazywane ustnie z pokolenia na pokolenie. Wraz z I Zjazdem Rodu Feretów pojawiła się potrzeba utrwalenia wiedzy, oraz relacji świadków historii. Wspomnienia Czesława zostały umieszczone w kronice rodzinnej, która jest nośnikiem pamięci rodziny Feretów. Spisanie relacji stanowi symboliczne przejście grupy od oralności do piśmiennictwa w kontekście przekazywania wiedzy o przeszłości. Moment ten jest również przekształceniem pamięci komunikacyjnej w pamięć kulturową ${ }^{28}$. Kronika jest zatem instytucjonalnym nośnikiem pamięci, który stanowi fundament tożsamości grupy oraz jest dowodem na ciągłość rodziny. Tak więc pamięć o przeszłości musi opierać się na pewnych nośnikach pamięci, nośnikach zinstytucjonalizowanych. Poprzez wytworzenie materialnych nośników pamięci przekaz o przeszłości już nie jest relacją świadków, lecz instytucjonalnym medium pamięci.

Ponownie odwołując się do poglądu Shilsa mówiącego o tym, że tradycja to twory uznane za wyjątkowe i godne utrwalania z uwagi na ich domniemaną
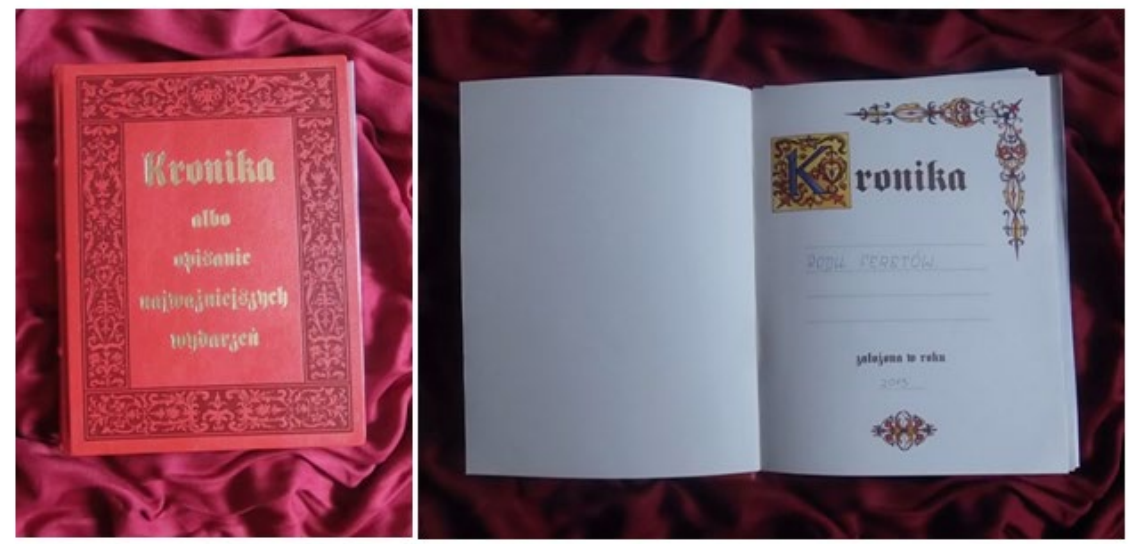

Ilustracja nr 4. Kronika rodzinna. Źródło - archiwum prywatne

dawność, niezależnie od tego, czy ich związek z przeszłością jest ciągły,

${ }^{28}$ M. Saryusz-Wolska, Wprowadzenie, op. cit., s. 27-31. 
można stwierdzić, że wizualne nawiązanie kroniki do starodruków z elementami piśmienniczymi lub do inkunabułów ${ }^{29}$ miało na celu wywołać w uczestnikach zjazdu wrażenie, że mają do czynienia z czymś ważnym, z czymś, do czego należy podejść z szacunkiem. Na zjeździe kronika była ostrożnie przekazywana z rąk do rąk, gdyż każdy miał obowiązek się do niej wpisać. Burzliwe dyskusje i stres towarzyszący doborowi słów wskazują na to, jak wielką wagę uczestnicy przywiązali do owej księgi. Dzięki jej wizualnemu nawiązaniu do czasów dawnych wytworzyła się świadomość tego, że może przetrwać wieki. Nawet imitacja zwięzów umieszczonych na jej grzbiecie, która świadczy o stylizacji na książkę szytą, metaforycznie mówiąc, zapewnia kronice materialną trwałość. Takie przekonania wyrażają zawarte w kronice wypowiedzi dotyczące więzi rodzinnych, tradycji oraz pamięci: „Składamy uroczystą przysięgę, że dochowamy wierności w kultywowaniu tradycji rodzinnych”; „Z Wierzbki Górnej ród Feretów się wpisuje, tradycji dotrzymać obiecuje". Wpisy tego typu świadczą o tym, że sami uczestnicy zjazdu traktują go jako tradycję, a świadomość nowości nie przeczy chęci jej podtrzymywania. W kilku wypowiedziach wspominano o pamięci, jednak w różnych kontekstach. Niektórzy mówili o tym, że „,wspomnienia ze zjazdu na długo zostaną w naszej pamięci”, dając świadectwo o wyjątkowości spotkania oraz konieczności przypominania o nim. Inni obiecywali ,pamiętać o żyjących Feretach, a w szczególności o naszych przodkach”. Dobrym przykładem skuteczności idei zjazdu jest wpis dziewięcioletniej Martynki, która wskazuje na to, że najważniejszą wartością rodzinną jest pamięć o rodzinie oraz wszelkie formy, które będą przypominać o przeszłości i tradycjach rodzinnych. Treść wpisu brzmiał następująco: „Cieszę się, że jestem z rodu Feretów. Mam nadzieję, że zasłużę sobie na nagrodę Fereta za pamięć i przypominanie o tej wielkiej rodzinie".

${ }^{29}$ Pragnę bardzo serdecznie podziękować dr Joannie Pietrzak-Thebault za pomoc przy analizie kroniki. 


\section{Mechanizmy wytwarzania wynalezionej tradycji}

Reasumując, I Zjazd Rodu Feretów to wynaleziona tradycja, której konstrukcja opiera się na dwóch filarach. Pierwszy z nich to wytworzenie relacji między przeszłością a teraźniejszością. Poznanie przeszłości rodziny oraz wszystkich jej członków pozwoliło na rozpoczęcie procesu konsolidacji grupy oraz identyfikacji jednostek z rodziną. Wynaleziona tradycja propagowała wartości, które okazały się niezbędne do podtrzymania tożsamości oraz samej tradycji. Drugim filarem, na którym zbudowana została wynaleziona tradycja, jest pamięć. Jednocześnie zabiegi zastosowane na zjeździe ukształtowały pamięć zbiorową, gdyż wiedza na temat przeszłości rodziny opiera się na sposobie przedstawiania jej na zjeździe. Pamięć stanowi również jedyną szansę na podtrzymanie nowej tradycji oraz powstałych więzi rodzinnych. Dopełnieniem tej szansy jest wytworzenie materialnych nośników pamięci, takich jak kronika rodzinna, broszury, przypinki, drzewo genealogiczne, hymn oraz statuetki Feret 2013, gdyż są one pamiątkami z wydarzenia, które ukształtowało rodzinę Feretów. Wszelkie przenikające się funkcje wynalezionej tradycji miały na celu zaszczepić w uczestnikach chęć postępowania zgodnie z tradycją i rodzinnymi wartościami.

Odwołując się do definicji wynalezionej tradycji Wojciecha Burszty, można powiedzieć, że I Zjazd Rodu Feretów był zbiorem praktyk kulturowych, „które wyrażają pamięć o wartościach, normach, wydarzeniach czy postaciach z przeszłości na zasadzie ich powtarzania i przypominania dzisiaj żyjącym jednostkom, aby wywołać w nich uczucie, że są w jakiś sposób powiązani z historią i tradycją" ${ }^{30}$ danej grupy. Współczesna tradycja wynaleziona, która była świadectwem przemian i symptomem problemów zglobalizowanego świata, okazała się ich rozwiązaniem. Na zakończenie pozwolę sobie zacytować Hobsbawma, który stwierdził, że badając wynalezione

${ }^{30} \mathrm{~W}$. Burszta, Różnorodność i tożsamość..., op. cit., s. 112-113. 
tradycje, bada się kontrast „między nieustanną zmiennością i nowością współczesnego świata a próbą uczynienia przynajmniej niektórych obszarów życia społecznego niezmiennymi"’31.

Niniejszy artykuł powstał na podstawie pracy licencjackiej pod tytułem Wspótczesna , tradycja wynaleziona" na przykladzie zjazdu rodzinnego Feretów, napisanej pod kierunkiem dra Marcina Jewdokimowa. Praca jest dostępna w archiwum Uniwersytetu Kardynała Stefana Wyszyńskiego w Warszawie.

\section{Bibliografia:}

Jan Assmann, Pamięć kulturowa. Pismo, zapamiętywanie i polityczna tożsamość $\quad w$ cywilizacjach starożytnych, tłum. A. Kryczyńska-Pham, Wydawnictwo Uniwersytetu Warszawskiego, Warszawa 2008.

Krzysztof Bulzacki, Henry Komański, Szczepan Siekierka, Ludobójstwo dokonane przez nacjonalistów ukraińskich na Polakach $w$ województwie lwowskim 1939-1947, Wrocław 2006.

Wojciech Burszta, Różnorodność i tożsamość. Antropologia jako kulturowa refleksyjność, Wydawnictwo Poznańskie, Poznań 2004.

Noa Gedi, Yigal Elam, Collective memory - What is it?, Presses Universitaires de France, Paryż 1950.

Maurice Halbwachs, Społeczne ramy pamięci, tłum. M. Król, PWN, Warszawa 1969.

Eric Hobsbawm, Terence Ranger, Tradycja wynaleziona, tłum. M. Godyń, F. Godyń, Wydawnictwo Uniwersytetu Jagiellońskiego, Kraków 2008.

${ }^{31}$ E. Hobsbawm, T. Ranger, Tradycja wynaleziona, op. cit., s. 10. 
Waldemar Kuligowski, Prefabrykacja tradycji, promocja dziedzictwa, [w:] Antropologia wspótczesności. Wiele światów, jedno miejsce, Universitas, Kraków 2007.

Mirosława Marody, Anna Giza-Poleszczuk, Przemiany więzi spolecznych, Wydawnictwo Naukowe Scholar, Warszawa 2004.

Filip Pazderski, Czemu przeszłość się pamięta - wokót dyskusji na temat ksztaltowania się pamięci zbiorowej, „DRUMLA-Nasza Czytelnia”, $\mathrm{nr} 2$.

Magdalena Saryusz-Wolska, Pamięć zbiorowa i kulturowa. Wspótczesna perspektywa niemiecka, red. M. Saryusz-Wolska, Kraków 2009.

Modi memorandi. Leksykon kultury pamięci, red. M. Saryusz-Wolska, R. Traba, Wydawnictwo Naukowe Scholar, Warszawa 2014.

Edward Shils, Tradycja, tłum. J. Szacki, [w:] Tradycja i nowoczesność, red. J. Kurczewska, J. Szacki, Wydawnictwo Czytelnik, Warszawa 1984. 


\section{The Family Reunion as an Example of the Invented Tradition}

The purpose of this article is to present the functioning of contemporary invented tradition on the example of the Feret's family reunion. The article contains the definitions of tradition, invented tradition, collective memory, cultural memory and memory space. It also describes the relationships between tradition and globalization. The analysis of the reunion depicts a construction of invented tradition and includes its features; it has been based on the family chronicle, the anthem and the presentation of the family's history. This particular invented tradition has built a social identity and composed a response to the problems of the present world.

Keywords: collective memory, cultural memory, tradition, invented tradition, globalization, identity, family. 